\title{
Sports Talents Selection of Early-Age Athletes in Central Java using Natural and Scientific Methods
}

\author{
Soedjatmiko $^{1}$, Wahadi $^{2}$ \\ \{ soedjatmiko@mail.unnes.ac.id ${ }^{1}$, wahadipssi@mail.unnes.ac.id ${ }^{2}$ \} \\ Universitas Negeri Semarang, Semarang, Indonesia ${ }^{12}$
}

\begin{abstract}
This study aims to obtain data on early age athletes' sports talents in Central Java. Researchers strive to collect these data with natural methods, and scientific methods follow the results of natural methods. Then, the researchers mapped the talents of early-age athletes based on the region's potential in Central Java. Based on the data, data on junior athletes in Central Java were 285 athletes. They consisted of 173 men and 112 women, coming from 25 leading sports in Central Java. Furthermore, from 285 sports talented athletes, a natural selection test was conducted. The natural selection results obtained as many as 251 sports talented athletes. The brand consists of 151 male athletes and 100 female athletes. A scientific selection test was held. From the scientific selection, 230 athletes who were declared as talented athletes of sports were selected as a result of natural and scientific selection.
\end{abstract}

Keywords: sports talent, early-age athletes, natural and scientific methods.

\section{Introduction}

Sports talent scouting is an effort to find athletes who are expected to have high achievements. The talent scouting process does not stop until the discovery of prospective athletes. Scouting and early guidance must be considered as continuous processes.

The identification of early age sports talent is divided into three steps, namely: 1). Identification of talent, 2). Talent Selection, 3). Talent development [1]. Talent identification is a screening of the potential owned by children or adolescents through physical, physiological, and motor skills test to identify the abilities of their sports talents. The results are used to estimate whether the child or adolescent will succeed in training and obtain the highest performance.

Talent selection is screening for young athletes (children and adolescents) who have participated in certain sports that are carried out through physical, physiological, and motor skills tests. It functions to select the abilities and skills owned by these athletes in the sports, so they can develop it until they succeed. Talent development is 
a process of giving treatment to a potential athlete in the sport that is occupied according to his talent.

The optimal performance is only possible if the athlete has the potential or talent that is quite ideal-handled by professional trainers with the application of directed, systematic, and valid coaching methods. The consequences of this need to be sought or filtered talent through talent monitoring, marketing, nursery, education, and training in sports achievements. $60 \%$ of athletes' top achievements are determined by talent, hard work, high discipline from the sportsmen themselves [2].

In general, talent can be interpreted as something that is owned by someone when he was born. He can manifest through heredity and personal factors that are obtained from a mixture of two cells originating from the father and mother by genetic law. This heredity can be different from one individual to another in a family. At the same time, the person is something that exists, something obtained and can differ from one individual to another, including siblings [3].

\subsection{Characteristics of Talented Children in Sports}

According to Bloom, a child's sports career is divided into three stages: the initial stage, the developing stage, and the perfect stage. The steps will be described as follows:

\subsection{Initial Phase}

. At this stage, children involved in sports have the talent to show a very loving nature of the sport. Love is also shown by being a fan of athletes who excel in the sport. At this stage, the trainer should not emphasize mastery of techniques but still maintain that children can practice happily. Trainers and parents in giving rewards must be based on the process, not results.

\subsection{Development Stage}

. At this stage, children begin to go crazy over occupied sports. The child already feels that he can be an athlete and not just a participant. The athlete's motivation and dedication increases; he even strives to improve his skills to improve. The child's orientation changes to the achievement of his achievements and interests to deepen the knowledge of the practice that is practiced. Athletes should be trained by coaches who are more skilled and have emotional connections with their athletes. Parents are expected to provide moral and financial support so that their performance continues to improve.

\subsection{Stage of Perfection}

. The Perfection Stage is obtained after the needs at the developmental stage have been fulfilled, and achievements continue to increase. At this stage, the practiced sport dominates his life, and the athlete spends his time and effort to achieve the highest achievements. The role of parents is not too significant because their children are already more independent. The coach will always demand to always excel from time to time. Relationships with trainers can be more positive or negative, depending on the trainer's approach. 
Table 1. Talented Children in Sports' Characteristic Model According to Bloom.

\begin{tabular}{|c|c|c|c|c|}
\hline \multirow[t]{2}{*}{ No } & \multirow[t]{2}{*}{ Individual } & \multicolumn{3}{|c|}{ Career Stages } \\
\hline & & Beginning & Developing & Perfect \\
\hline 1 & $\begin{array}{l}\text { Performance } \\
\text { (athlete/child) }\end{array}$ & $\begin{array}{l}\text { Cheerful, happy, } \\
\text { spiritful } \\
\text { special }\end{array}$ & Passionate, dedication & $\begin{array}{l}\text { Obsession, responsi- } \\
\text { bility }\end{array}$ \\
\hline 2 & Mentor (Coach) & $\begin{array}{l}\text { Kind, full of loved, } \\
\text { orientation to } \\
\text { process }\end{array}$ & $\begin{array}{l}\text { Strong, decisive, } \\
\text { respectful, } \quad \text { skilled, } \\
\text { provide positive chal- } \\
\text { lenges }\end{array}$ & $\begin{array}{l}\text { Fear / be respected, } \\
\text { bring success, be } \\
\text { emotionally bound }\end{array}$ \\
\hline 3 & Parents & $\begin{array}{l}\text { Share joy and } \\
\text { enthusiasm, sup- } \\
\text { portive, positive }\end{array}$ & $\begin{array}{l}\text { Willing to sacrifice } \\
\text { (including financial), } \\
\text { limit children's activi- } \\
\text { ties }\end{array}$ & \\
\hline
\end{tabular}

\subsection{Talent Identification}

The program of identifying talented athletes has been a primary concern of countries with rapidly developing sports achievements. As an illustration, the State of East Germany at the 1968 Olympics in Mexico won 9 gold medals. Eight years later, after the country ran an intensive talent identification program, he achieved success at the 1976 Olympics in Montreal by winning 47 gold medals. Likewise, in facing the Sydney Olympics in 2000, Australia has implemented a program of identifying and developing talented athletes through schools with the science and technology approach. It has been proven that Australia is able to occupy the top 4 of the world in the Sydney Olympics after the United States, Russia, and China. The program of identifying talented athletes in these countries has been developed and implemented to support adequate resources. It is not only funding from the government and the community, but also expert support through a cross-cutting and interdisciplinary scientific approach.

The identification of talented athletes must start from the underlying assumption that each individual is given the same opportunity to participate in various sports activities and develop his potential to reach peak performance. Identification and selection must be made validly and reliably so that the results can be used to predict the athlete's expected performance.

It was realized that bringing up high-achieving athletes was a long and complicated process. In addition to the talent deposition that exists in an athlete, the athlete's success is also determined by how the athlete's potential is nurtured and developed through a conducive training process. Talent identification aims to predict with the optimum chance of success to follow and complete the training process to reach the peak achievement.

\subsection{Sports Talent Selection Model}

Identifying talented athletes can be done in two ways, namely: (a) natural models and (b) scientific models. 
a) Natural model is a selection made naturally. This model adheres to the belief that an athlete who chooses a particular branch of sport matches his talent. This belief is undoubtedly true, and there is a possibility of being wrong. It means that the athlete can be high achievers, and vice versa can be an athlete whose performance is slow because the choice of the sport that he is doing is not following the real potential in him.

b) A scientific model is a selection model for prospective athletes by comprehensively applying scientific rules. Athletes are identified based on standard measurements such as body size, heart-lung conditions, and psychological conditions, and are performed by people who have the ability in their field. The determination of specific measurements needs to be adjusted to the specifications of the sport. For example, sports that require height/weight (such as basketball, volleyball, and throwing numbers) certainly cannot be compared to sports that require speed, reaction time, coordination, and strength (such as: sprinting, judo and jumping)

Table 2. Battery Talent Sports Identification Test

\begin{tabular}{lll}
\hline Measured Aspects & Test Form & Unit of Measure \\
\hline Body Shape and Size & $\begin{array}{l}\text { 1. Height } \\
\text { 2. body weight } \\
\text { 3. Sitting height } \\
\text { 4. Arm span }\end{array}$ & Centimeter \\
& & Kilogram \\
& & Centimeter \\
& & \\
Physical Ability & 1. Throw catch & Frequency \\
- Eye-hand coordination & 2. Throw the basket- & Meters \\
- Arm muscle strength & ball & Centimeter \\
- Leg muscle explosive & 3. Jump straight & 4. Run back and forth \\
power & 5. Run 40 m & Seconds \\
- agility & 6. Multi-stage run & Seconds \\
- speed & & Series-level \\
- aerobic capacity & & \\
\hline
\end{tabular}

\subsection{Early Age Sports}

Early age children, according to growth and development, is the age period between 6-14 years [4]. This period is a critical period to determine the achievements in the future. At this age, it is a potential that has the potential for coaching so that in the future, it will produce the highest possible achievements.

The age of the beginning of the sport is different from one branch to another. The difference is based on the specifications of the sport that is occupied. Early age is also based on the growth and development of early-age athletes. Starting a too early sport will cause injury, growth disturbance, and even boredom and drop out on the 
sport branches. Conversely, delays in starting in sports will have difficulty getting top achievements.

Sports talent scouting must consider the specific branch of sport. Physical components, height, skills, and psychological sports are different from one another. The age of the beginning of the sport is different from one branch to another. Those differences are based on the specifications of the sport that is occupied. Below is presented a table that can be used as a basis for determining the age of beginning of specialization and the peak achievement of athletes in each sport [5].

Table 3. Starting Age of Training, Specialization and Peak Achievement

\begin{tabular}{|c|c|c|c|c|}
\hline No & Sports Branch & $\begin{array}{l}\text { Starting Age of } \\
\text { Training }\end{array}$ & Specialization & Peak Achievement \\
\hline 1 & Athletic & $10-12$ & $13-14$ & $18-23$ \\
\hline 2 & Basketball & $8-9$ & $10-12$ & $20-25$ \\
\hline 3 & Boxing & $13-14$ & $15-16$ & $20-15$ \\
\hline 4 & Bicycle Racing & $14-15$ & $16-17$ & $21-24$ \\
\hline 5 & Platform Diving & $6-7$ & $8-10$ & $18-22$ \\
\hline 6 & Fencing & $8-9$ & $10-12$ & $20-25$ \\
\hline 7 & Female Gymnastic & $6-7$ & $10-11$ & $14-18$ \\
\hline 8 & Male Gymnastic & $6-7$ & $12-14$ & $18-24$ \\
\hline 9 & Rowing & $12-14$ & $16-18$ & $22-24$ \\
\hline 10 & Football & $10-12$ & $11-13$ & $18-24$ \\
\hline 11 & Swimming & $3-7$ & $10-12$ & $16-18$ \\
\hline 12 & Tennis & $6-8$ & $12-14$ & $22-25$ \\
\hline 13 & Volley & $11-12$ & $14-15$ & $20-25$ \\
\hline 14 & Weightlifting & $11-13$ & $15-16$ & $21-28$ \\
\hline 15 & Wrestling & $13-14$ & $15-16$ & $24-28$ \\
\hline 16 & Badminton & $8-9$ & $14-15$ & $18-24$ \\
\hline 17 & Hockey & $12-14$ & $16-18$ & $22-25$ \\
\hline 18 & Softball & $10-12$ & $14-16$ & $18-24$ \\
\hline 19 & Archery & $11-12$ & $17-18$ & $20-28$ \\
\hline 20 & Pencak silat & $10-11$ & $15-16$ & $18-22$ \\
\hline 21 & Hand Ball & $12-13$ & $15-16$ & $18-24$ \\
\hline 22 & Table Tennis & $7-8$ & $10-12$ & $18-24$ \\
\hline 23 & Water Polo & $12-13$ & $15-16$ & $18-25$ \\
\hline 24 & Horse Riding & $13-15$ & $17-18$ & $20-25$ \\
\hline 25 & Sailing & $12-13$ & $15-16$ & $18-24$ \\
\hline 26 & Judo & $12-13$ & $15-16$ & $18-25$ \\
\hline 27 & Karate & $12-13$ & $15-16$ & $18-25$ \\
\hline
\end{tabular}

\section{Methods}

Researchers used sports talent selection for early athletes to obtain data on potential early athletes in Central Java. In scouting early childhood, talent is known for identifying talent, talent selection, and sports talent development for young athletes. 
Talent identification is a screening (Screening) conducted on children and adolescents through a series of physical, physiological, and motor skills tests as an instrument of selection to identify children who are sports talented so that they can achieve peak performance [6].

The general objective of identifying children and adolescents' talents is to increase the standard of sporting achievement, namely to increase the standard of achievement in higher competitions, to maximize the talents possessed by athletes in certain sports to be more successful in higher competitions. Specifically, the objectives of talent identification are: 1) applying the talents of children and adolescents with the opportunity to develop their skills. 2) optimistic about all individuals on the success of sports achievements, 3). Increase sufficient stimuli for ongoing participation 4). Control the discrepancy of sports occupied by children and adolescents, thereby reducing the possibility of injury when exercising.

Talent selection can be made in three ways: natural ways, scientific ways, and based on regional potential. The natural way is an approach to identify the child's talents through natural or natural steps of the child's development during sports activities. Through this natural selection, it is assumed that children's sports talent is obtained from sports treatment, which is often accidentally performed by children during their development. Weakness in natural talent selection always experiences delays and evaluates individual performances.

Scientific approach is an approach to identify children's talents by selecting the prospects of natural abilities that children have had directed at sports that are following their potential and carried out in the form of scientific tests by scientists.

Regional potential based talent selection is a selection based on the potential of the area where the child or adolescent lives. The potential in question can be in the form of natural conditions in the area, the social environment in the area, the sporting traditions in the area concerned, and the influence of the informal environment and peers.

To get perfect results, the researchers tried to combine the three tests into one series of tests. The goal is to supplement the shortcomings of one method of determining sports talent with another method, also in order to maximize the advantages of one method to be used in combination methods.

To get the ideal sample is to research on multi-event sports events. Events that are attended by athletes ages 8-12 years or elementary school age and are multi-event are the most appropriate holding of Student Sports Week. Almost all student sportsmen attended this activity in Central Java. 


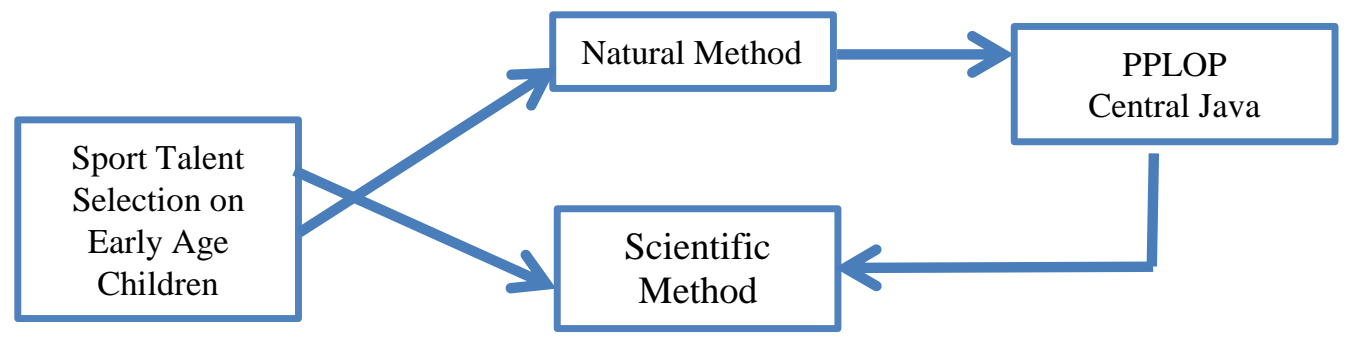

Fig. 1. Research flowchart

The research identified early-age sports talent throughout Central Java. Researchers try to naturally select talents possessed by early childhood. The result is a natural test then proceed with a scientific test. The scientific test used is test 1) Anthropometric quality test 2). Predicted height test for children when they are adults.

The type of research used is qualitative research. While the research design used is Sequential Exploratory Design. Sequential Exploratary Design is an analysis where data collection and data analysis are qualitatively carried out as a prefix for the implementation of the analysis, further data collection and subsequent data analysis is done quantitatively. Sequential Exploratory Design was chosen as a research procedure when researchers need to make an instrument, or existing instruments are considered to be inappropriate or inappropriate so this research needs to review new research instrument.

\section{$3 \quad$ Results and Discussions}

\subsection{Natural Selection Results}

From all junior athletes in Central Java, there were 285 athletes from all of Central Java. They consisted of 173 men and 112 women. Each comes from 25 sports which are the main sports in Central Java.

\subsection{Scientific selection results}

Furthermore, from 285 sports talented athletes, a natural selection test was conducted. The natural selection results obtained as many as 251 sports talented athletes. The brand consists of 151 male athletes and 100 female athletes. From the results of the natural selection then a scientific selection test was held.

From scientific selection, we got data from 251 athletes then tested with scientific tests with 20 meter running tests, sit and reach tests, dynamometer grip tests, dynamic balance, sit ups, push-ups, pull ups, vertical jumps, and vo2 max.

The results of scientific selection of talented athletes in Central Java can be seen in the following table: 
Table 4. The Scientific Selection's Result of Talented Athletes in Central Java

\begin{tabular}{clcc}
\hline NO & & Test Result Categories & Total \\
\hline 1 & Excellent & & 3 \\
2 & Good & & 49 \\
3 & Enough & & 111 \\
4 & Poor & & 82 \\
5 & Very Poor & & 6 \\
\hline & & Total & 251 \\
\hline
\end{tabular}

From these results can be displayed in the diagram as below:

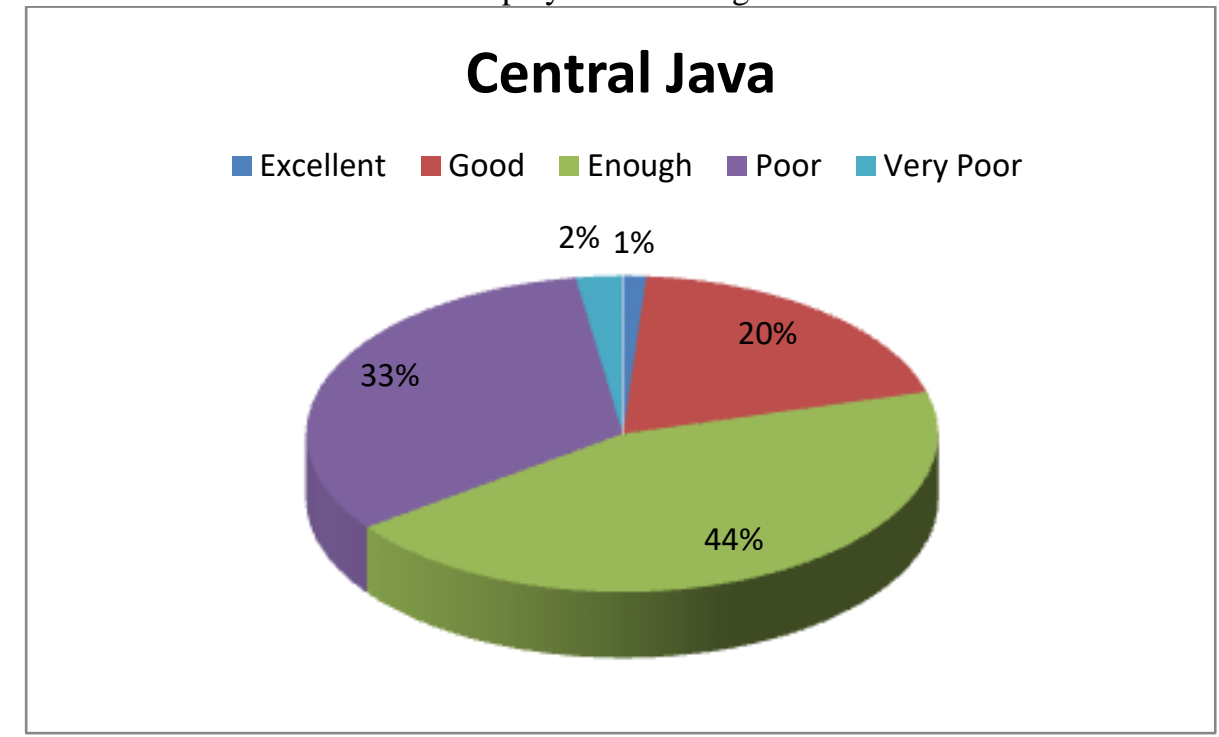

Fig. 2. Diagram of The Scientific Selection's Result of Talented Athletes in Central Java

Furthermore, the results of scientific selection can be broken down again based on sex as mentioned below:

Table 5. The Scientific Selection's Result of Talented Athletes in Central Java Based on Sex

\begin{tabular}{lllll}
\hline No & Categories & Male & Female & Total \\
\hline 1 & Excellent & 3 & 0 & 3 \\
2 & Good & 37 & 12 & 49 \\
3 & Enough & 76 & 35 & 111 \\
4 & Poor & 34 & 48 & 8 \\
5 & Very Poor & 1 & 5 & 6 \\
\hline \multicolumn{2}{r}{ Total } & 151 & 100 & 251 \\
\hline
\end{tabular}




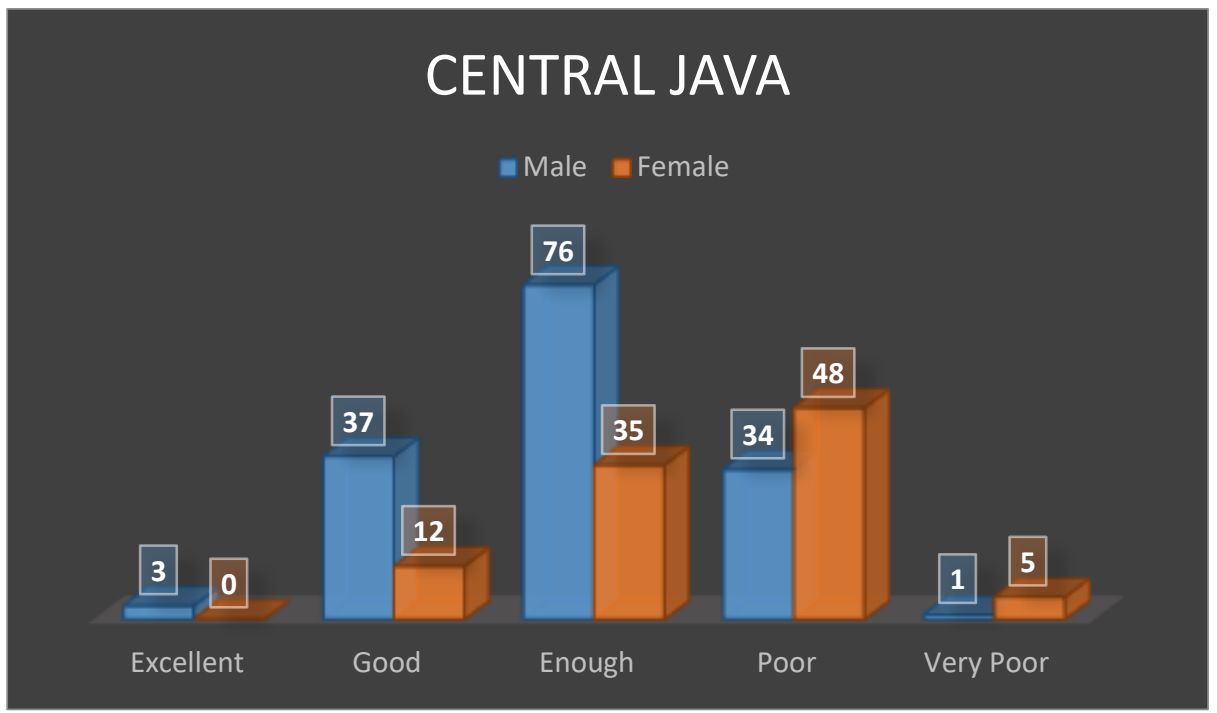

Fig. 3. Chart of The Scientific Selection's Result of Talented Athletes in Central Java Based on Sex

\section{Conclusion}

From the scientific selection, 230 athletes who were declared as talented athletes of sports were selected as a result of natural and scientific selection. The natural selection results obtained as many as 251 sports talented athletes. The brand consists of 151 male athletes and 100 female athletes. From the results of the natural selection then a scientific selection test was held.

\section{Acknowledgements}

Researchers are grateful to those who have helped carry out this research, especially the Head of the Student Sports Education and Training Center, who provided the athletes with the tools to be used as research objects. Also, to the dean of the Faculty of Sports Science who has provided the opportunity for researchers to conduct research.

\section{References}

[1] Australian Institue of Sport. 2005. National Talent Search Program. http://www.ais.org.au /talent/what/23/01/2020.

[2] Undang-undang RI No 3 tahun 2005.Sistem Keolahragaan Nasional.Jakarta: Biro Hukum Kemenpora Republik Indonesia. 
[3] KONI Pusat. 2014. Grand Strategi Pembangunan Olahraga Prestasi Nasional 2014 2024. Jakarta: KONI Pusat.

[4] Litbang KONI. 2014. Analisis Kekuatan, Tantangan, Peluang dan Strategi Indonesia Menyongsong Multi Ajang. Jakarta: KONI Pusat.

[5] KONI Pusat. 2014. Grand Strategi Pembangunan Olahraga Prestasi Nasional 2014 2024. Jakarta: KONI Pusat

[6] Undang-undang RI No 3 tahun 2005.Sistem Keolahragaan Nasional.Jakarta: Biro Hukum Kemenpora Republik Indonesia

[7] Balyi, I., 2005. Sport System Building and Long Term Atlete Development in British Columbia. http://google.com/24/01/2020

[8] Bompa, T.O.2002. Theory and Methodology of Training, The Key to Atlet Performance $\left(4^{\text {nd }}\right.$ ed). Dubugue, Iowa:Kendal/Hunt Publishing Company.

[9] Kerlinger. N. Fred. 2000. Asas-asas Penelitian Behavioral. Jogyakarta: Gajah Mada Univercity Press.

[10] Olympic Solidarity. 2010. Manual Administrasi Olahraga. Canada. Roger Jackson \& Associates Ltd.

[11] Masterman, Guy.2004. Strategic Sports Event Management an International Aproach. Amsterdam. Elsivier Butterworth Heinemann.

[12] Mullin, Bernard J., Hardy, Stephen., Sutton, William, A. Sport Marketing. Canada. Human Kinetics Publisher. 